\title{
食品媒介寄生虫による食中毒
}

\section{Food-borne Parasitic Infection as Food Poisoning}

\author{
杉山 広 \\ (国立感染症研究所寄生動物部)
}

\section{Hiromu SugiYama}

(Department of Parasitology, National Institute of Infectious Diseases,

Toyama 1-23-1, Shinjuku-ku, Tokyo 162-8640)

\section{はじめに}

食の安全・安心は, 我々にとって大きな関心事となっ ている。この食の安全を担保する法律として, 我が国で は「食品衛生法」が重要な役割を果たしてきた。本法は 「食品の安全性の確保のために公衆衛生の見地から必要 な規制・措置を講じることにより，飲食に起因する衛生 上の危害の発生を防止し, 屯って国民の健康の保護を図 ることを目的とする (第 1 条)」として，1947 年に制定 された法律である。この条文に書かれている「飲食に起 因する衛生上の危害」を，「飲食に起因する健康被害」と 読み替え, さらにこれを「食中毒」としてとらえるのが, 最近の行政上の, すなわち厚生労働省の方針となってい $ろ^{16,20)}$ (http://www 1.mhlw.go.jp/topics/syokueihou /tp1228-1_13.html).

\section{食中毒の原因として対策を取る寄生虫}

寄生虫む「飲食に起因する衛生上の危害」を引き起こ すことから，「食中毒」の原因物質としてとらえる必要が ある. 我が国では, 生鮮魚介類などの生食が嗜好され, 食文化としても定着していることから, 食品に媒介され る寄生虫症の発生を認めることは, 経験的にも知られて いる。この食品媒介寄生虫による疾患への対策を検討す るため, 1997 年 9 月に当時の厚生省において, 食品衛 生調査会食中毒部会食中毒サーベイランス分科会が開催 された，そのときにまず，我が国において特に対策が必 要な寄生虫が指定された。検討に際しては,

イ）全国的に発生が多いむの，あるいは近年増加傾向 にあるあの.

ロ）海外では発生が多く日本であ増加が懸念されるあ の.

八）発生は多くなくとも重篤な被害が出る恐れのある あの.

焉162-8640 東京都新宿区戸山 1-23-1
という三つの条件が考慮され，以下の 14 種類の寄生虫 が対象として指定されることになった。

1) 原虫類 (4 種類)：単細胞の寄生虫（著者注）

クリプトスポリジウム，サイクロスポーラ，ジアルジ ア，赤痢アメーバ

2) 蠕虫類 (計 10 種類)：多細胞の寄生虫,「ぜんちゅ う」(著者注)

(1) 生鮮魚介類により感染するもの（6 種類）

アニサキス, 旋尾線虫, 裂頭条虫, 大複殖門条虫, 横 川吸虫，顎口虫

（2）その他の食品 (獣生肉等)により感染するすの（4 種類)

肺吸虫，マンソン孤虫，有鉤囊虫，旋毛虫

これら寄生虫の感染を予防するために当面取るべき対 策として，まず「国民及び関係者への安全な攝食方法等 についての普及啓発」が挙げられた。また「国内外での 食品の寄生虫污染の実態及び当該疾患の発生状況につい ての情報把握」などの事項も取るべき対策とされた ${ }^{17)}$ (http:/ / www 1.mhlw.go.jp/houdou/0909/h0917-1. html).

\section{食品衛生法に則した食中毒の届出}

寄生虫疾患の発生状況についての情報を把握するに は，法に則した届出を確実とすることが有効な手段とな る. 寄生虫も「食中毒」の原因物質としてとらえること から，飲食に起因した寄生虫症が発生すれば，これを食 中毒として届け出ることになる.

「食中毒」が発生した場合の届出に関しては, 食品衛生 法の第 58 条に規定がある。その第 1 項には「食品, 添加 物, 器具むしくは容器包装に起因して中毒した患者もし くはその疑いのある者を診断し，またはその死体を検案 した医師は，直ちに最寄りの保健所長にその旨を届け出 なければならない」と記載されている（医師の届出は文 書，電話または口頭により 24 時間以内に行わなければ 
ならない：食品衛生法施行規則第 72 条)。実際には，「食 中毒患者等届出票」の当該箇所（原因）に，食中毒事件 票の「食中毒病因物質の分類」（表 1）にリストアップさ れている病因物質を記載して, 医師から保健所に, 食中 毒事案としての届出が行われることになる. 医師以外の 者からの報告・苦情等は, 食中毒の疑いのある事案とし て保健所が受け付ける ${ }^{20)}$.

\section{食品衛生法に則した寄生虫症の届出}

「食中毒病因物質の分類」を見ると, 寄生虫が食中毒の 病因物質として,「22. その他」という範疇で取り上げら れていることがわかる(表 1). しかあ具体的な例とし て,「クリプトスポリジゥム, サイクロスポラ, アニサキ ス」の 3 種類の寄生虫が「等」という文字を付して掲げ られている。この 3 種の寄生虫は, 上述の食中毒部会で 検討・指定された 14 種類の中に含まれる.

このように寄生虫名が「食中毒病因物質の分類」の中 に例示された直接の契機は, 1999 年の食品衛生法施行 規則の一部改正にある. 改正に当たり当時の厚生省から 都道府県知事等に発出された通知を見ると, 「原虫及び 寄生虫による飲食に起因する健康被害についても食中毒 としての取扱いを明確にするために, 食中毒病因物質の 分類のその他にクリプトスポリジウム等の例示を掲げ た」と明記されている ${ }^{19)}$ (http://www 1.mhlw.go.jp/ topics/syokueihou/tp1228-1_13.html). 寄生虫を原因 とするあのであっても，「飲食に起因する衛生上の危害」 は「食中毒」として取扱い, 食品衛生法に基づいて事案 発生を届け出る。その結果として, 事故が調査され, 被 害の拡大が防がれ, 再発が防止される。このような寄生
虫症への対応に関する厚生労働省の見解には，現時点で も変更はない。

なお上述の通知では, 寄生虫を「原虫及び寄生虫」と いう形で記述している。「原虫」を寄生虫から分離し，ま た蠕虫を単に「寄生虫」として表現したものと考えられ る.

\section{寄生虫症の届出の実態}

上述の食品衛生法施行規則の一部改正以降, 食品衛生 法に則して届け出る寄生虫症に变化があったか, 食中毒 統計に見てみたい（表 2). すでに述べたように寄生虫 は, 食中毒の病因物質「その他」に分類されており, 具 体的な寄生虫として「クリプトスポリジウム, サイクロ スポラ, アニサキス」という 3 種類が例示されている. しかしながら実際には，蠕虫である「アニサキス，肺吸 虫, 旋尾線虫」の 3 種類を病因物質とする事案が, 食中 毒として届け出られたに過ぎない.

我が国では, 生鮮魚介類の生食が嗜好され, これを原 因とした寄生虫症の発生があることは経験的にも知られ ている。なかでもアニサキスは病気の原因として知名度 が高い.このアニサキス症の発生状況が，日本内視鏡学 会会員や同学会指導施設等を対象としたアンケートによ り調べられ，2001 年から 2005 年の 5 年間に 2,511 例 の症例 (年平均: 502 例) が集計されている9).このよう な成績も背景に, 最近でも年間に 2,000 例以上のアニサ キス症が，我が国で発生しているとの推定がある ${ }^{14)}$.し かしながら食中毒統計では, 例えば 2001 年から 2008 年までの 8 年間の届出は, 事件数 (患者数) がわずか 38 件 (38 名) によどまる (年平均の患者数は約 4.8 名). 発

\section{表 1. 食中毒病因物質の分類}

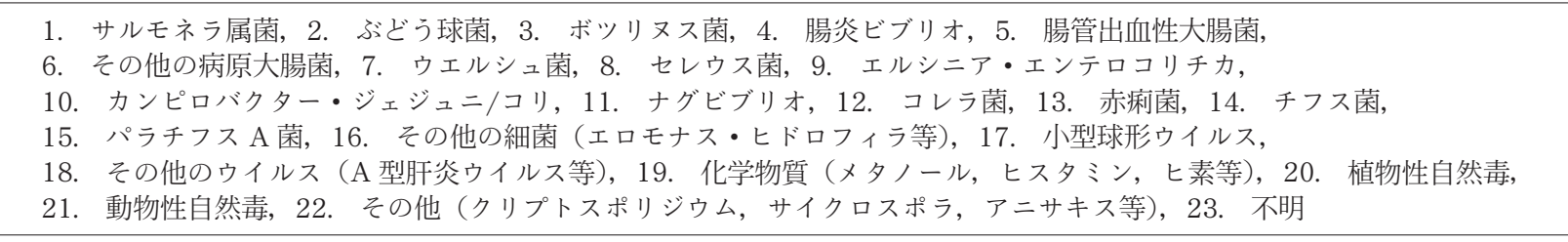

表 2. 食中毒の届け出（食中毒統計）

\begin{tabular}{|c|c|c|c|c|c|}
\hline 年 & $\begin{array}{l}\text { 食中毒届出総数 } \\
\text { 事件数 (患者数) }\end{array}$ & $\begin{array}{c}\text { 病因物質 }[\text { } \text { 他 }] \\
\text { 事件数 (患者数) }\end{array}$ & $\begin{array}{c}\text { アニサキス } \\
\text { 事件数（患者数） }\end{array}$ & $\begin{array}{c}\text { 肺吸虫 } \\
\text { 事件数（患者数） }\end{array}$ & $\begin{array}{c}\text { 旋尾線虫 } \\
\text { 事件数（患者数） }\end{array}$ \\
\hline 1999 & $2,697(35,214)$ & $1(1)$ & $1(1)$ & $0(0)$ & $0(0)$ \\
\hline 2000 & $2,247(43,307)$ & $5(53)$ & $4(4)$ & $0(0)$ & $0(0)$ \\
\hline 2001 & $1,928(25,862)$ & $1(1)$ & $1(1)$ & $0(0)$ & $0(0)$ \\
\hline 2002 & $1,850(27,629)$ & $2(25)$ & $0(0)$ & $0(0)$ & $0(0)$ \\
\hline 2003 & $1,585(29,355)$ & $1(1)$ & $1(1)$ & $0(0)$ & $0(0)$ \\
\hline 2004 & $1,666(28,175)$ & $5(8)$ & $4(4)$ & $1(4)$ & $0(0)$ \\
\hline 2005 & $1,545(27,019)$ & $8(8)$ & $7(7)$ & $0(0)$ & $0(0)$ \\
\hline 2006 & $1,491(39,026)$ & $7(23)$ & $5(5)$ & $0(0)$ & $0(0)$ \\
\hline 2007 & $1,289(33,477)$ & $8(20)$ & $6(6)$ & $1(2)$ & $0(0)$ \\
\hline 2008 & $1,369(24,303)$ & $17(47)$ & $14(14)$ & $0(0)$ & $0(0)$ \\
\hline $2009 *$ & $580(12,111)$ & $10(10)$ & $9(9)$ & $0(0)$ & $1(1)$ \\
\hline
\end{tabular}

* 2009 年は 2009 年 12 月 18 日までの速報值で, 同年 11 月中旬までの事件数（患者数）を示す. 
生の実態と食中毒統計との間に乘離があることは，疑う 余地もない. さらに,「クリプトスポリジウム, サイクロ スポラ」などを含めた原虫を原因物質とする事案は, 食 中毒としての届出が全くない（海外では原虫を原因とし た食品媒介の症例報告がある ${ }^{6)}$ ). 届出を確実とするよう な対策の検討が必要である.

ここで本稿では, 食中毒の原因として届出がある 3 種 類の寄生蠕虫, すなわちアニサキス, 肺吸虫及び旋尾線 虫について以下に概説し, 各寄生蠕虫に関する最近の話 題を提出したいと思う。これら寄生蠕虫症に対する理解 を深めて, 法に則した届出をさらに促進していただきた い.

\section{アニサキスとアニサキス症}

アニサキス症は古くからあった病気と考えられるが， その原因が Anisakis 亜科線虫 (の幼虫) であることは, 1960 年にオランダから報告された事例をむって初めて 確定された ${ }^{36)}$. 我が国では, 1964 年発生の 2 例が本症 としての最初の報告となる ${ }^{2}$. 当初は診断の方法がなく, 急激な腹部症状から開腹して患部が切除され, 病理学的 に初めてアニサキス症であると診断された事例がほとん どであった。しかし 1970 年代になると, 内視鏡での検 査と生検用鉗子での虫体摘出が普及し, 予想以上に多く の症例が発生していることが明らかとなった。

アニサキス症の原因となる虫種としては, クジラやイ ルカを終宿主とするAnisakis simplex（成虫が寄生する 宿主を「終宿主」と呼ぶ), マッコウクジラなどを終宿主 とするA. physeteris, そしてアザラシやトドを終宿主と する Pseudoterranova decipiens の 3 種が重要である. これらの幼虫が魚介類に寄生しており, 生きたままヒト に経口摂取されて消化管壁などに侵入し，アニサキス症 を引き起こす.

アニサキス症はその発症部位によって, 胃アニサキス 症, 腸アニサキス症及び消化管外アニサキス症に大別さ れる。我が国で発生するアニサキス症の大部分は，激烈 な胃痛（心窩部痛）と悪心・嘔吐を主な症状とする胃ア 二サキス症と考えられる，原因となる主な虫種は，患者 に由来する虫体の形態観察から, Anisakis simplex であ ると報告されてきた.

\section{アニサキス同胞種の分類学的解析}

A. simplex の分類に関しては, アイソザイム解析や塩 基配列解読などの先行研究の結果から,これを 3 種類の 同胞種，すなわち A. simplex sensu stricto（狭義の $A$. simplex), A. pegreffii, A. simplex C に分けるという考 えが提出され, 国際的にも受け入れらるようになってき た ${ }^{22)}$. 同胞種とは, 形態学的鑑別が困難であるが, 自然 下では（生殖隔離などで）互いに独立した関係にある種 の集団を意味する.

この新しい分類基準に基づく同胞種の解析が我が国で
も試みられた。その結果, 日本近海の魚に寄生するア二 サキスは，北日本（北海道に水揚げされた太平洋産のサ バ等）ではいずれも A. simplex sensu stricto, また南日 本（九州に水揚げされた日本海産・東シナ海産のサバ） ではおおむね $A$. pegreffiiであることが示された ${ }^{32,35)}$. 一方で, 北海道及び九州の人体症例に由来する虫体は, ほとんどすべてが A. simplex sensu stricto と同定され た ${ }^{33)}$. ヒトへの主たるアニサキスの感染源は，例えば九 州ではサバと言われていたが8)，その九州においては， 魚（サバ）寄生の優占種と患者由来の優占種とが異なる との結果が，アニサキスの同胞種解析で得られたことに なる34).

本州で水揚げされたサバ（日本海産・太平洋産）に由 来するアニサキスに関しても，同胞種レベルでの解析が 行われ，その結果，A. simplex sensu strictoとA. pegreffi とが混在して寄生していることが明らかとなっ た ${ }^{35)}$. したがって， サバを原因とする九州のアニサキス 症は, 地元産ではなく他の地域から搬入された A. simplex sensu stricto 陽性のサバを原因とする可能性が高 い. また, A. simplex sensu stricto が人体症例の主たる 原因である理由については, A. pegreffii に比べてサバの 筋肉から検出される虫体数がはるかに多いという検索結 果をむって，説明されている31). このように同胞種レベ ルでの解析は, 感染源の特定にも有用で, それを適切に 応用すれば，アニサキス症の発生予防に有効な啓発活動 が展開できると考えられた。

\section{アニサキスによる食物アレルギー}

食事をすることでアレルギー症状が起きる「食物アレ ルギー」に関して, 魚介類の消費量が多い我が国では, 魚介類屯重要な原因食物となってきた。しかしながら， この魚介類アレルギーは, 魚介類そのものがアレルゲン ではなく，魚介類に寄生するアニサキスが原因であると の興味深い知見が報告された ${ }^{10)}$ ，すなわち，サバの摂食 後に萇麻疹を呈した複数の症例や，さらに呼吸困難・心 悸六進などのアナフィラキシー症状を呈した症例につい て，アニサキス抗原を用いたスクラッチテストや血中抗 体価 (IgE) の測定が行われた. その結果, サバに対して は陰性，アニサキスに対しては陽性となることが示され た11,12).アニサキスに起因するアナフィラキシー症状 （血圧降下・呼吸不全・意識喪失）は, 散発事例だけでな く, 集団発生事例でも観察されている（カタクチイワシ が原因と推定された事例 ${ }^{1)}$ ).

一方で, 魚介類の生食習慣が我が国ほよ゙一般的ではな いはずのスペインにおいても，1995 年以降に，アニサ キスに対するアレルギーの症例が 150 例以上も報告さ れた ${ }^{3)}$. しかも, 皮膚炎, 喘息発作, 関節炎, 結膜炎なよ゙ 多彩な病態を示す症例が検出され，さらに虫体を殺滅す るような加熱・冷凍などの処理を魚に施しても, アニサ キスによるアレルギー反応の発現は必ずしも抑制されな 
いことが示された ${ }^{4)}$ 。このようなアニサキスに起因する アレルギーに関しては，クローニングを含めたアレルゲ ンの性状解析や発症に関連する免疫機構の解析などの研 究が着々と進展しており, 成果が上げられている5).

\section{アニサキス症の予防}

アニサキス症は, たとえ虫体 1 匹の感染であっても, 発症の危険性がある．個人レベルでの予防は海産魚介類 の生食を避けることに尽きる。アニサキスの幼虫は熱処 理 $\left(60^{\circ} \mathrm{C}, 1\right.$ 分以上) のみならず，冷凍処理で不活化さ れることが知られているので, 魚を冷凍し解凍後に生食 することにより感染を予防できる. 実際にオランダで は, ニシンに関して $-20^{\circ} \mathrm{C}$ 以下， 24 時間以上の冷凍を 1968 年に法律で義務づけた結果, 以降のアニサキス症 患者が激減した。冷凍以外の方法としては, 新鮮なうち に虫体の主要寄生部位である内臓を摘出してしまうな ぞ, 調理上の工夫も有効である. 事実, 捕獲後の時間の 経過で, アニサキスの幼虫は内臓から筋肉へと移行する ことを示す成績が，サバで報告されている31).

\section{肺吸虫と肺吸虫症}

ここで話題を肺吸虫に变えたい，肺吸虫症の原因とな る肺吸虫属の吸虫（吸虫は「ジストマ」とも呼ばれる） は, 熱帯加ら温帯・亜寒帯に属する世界の各地に, 約 40 種が分布する。人体症例は中間宿主のカ二（あるいはザ リガニ）を生で, あるいは不完全な調理で食べるという 伝統的な食習慣を持っ国々を中心に, 風土病的に発生し ている. 我が国にはウェステルマン肺吸虫（染色体構成 により 2 倍体型と 3 倍体型の 2 型に大別される), 宮崎 肺吸虫（我が国に固有の種と考えられてきたが, 最近で は中国原産のスクリアビン肺吸虫の亜種とする学説が有 力), 大平肺吸虫の 3 種が北海道を除く各地, 特に本州 中部以西に広く分布し, 前 2 種が人体寄生性である.

肺吸虫が生活環を営むためには，3 種類の宿主が必要 となる。まず, 成虫が寄生する終宿主としては, 肉食動 物（時に雑食動物）がその役割を果たす（ヒトす終宿 主).また幼虫が寄生する宿主（これを「中間宿主」と呼 ぶ）としては, 淡水産・汽水産の貝類が第 1 中間宿主と して, さらにザリガ二類や淡水産・汽水産のカ二類が第 2 中間宿主として, 順次それぞれの役割を果たす。我が 国では, 第 2 中間宿主である淡水産のカ二（モクズガ 二, サワガニ）がヒトへの感染源として重要である.

感染時に認める肺吸虫症の病態像は, 原因種により異 なる. すなわち, ウェステルマン肺吸虫 (3 倍体型) がヒ 卜に感染した場合は, 成虫が肺に形成された虫囊内で成 熟し, 咳嗽や血痰が主徴となる。胸部 X 線では結節影や 輪状影を認め, 結核や肺癌との鑑別が時に重要となる. これに対してウェステルマン肺吸虫（2 倍体型）では, 宮崎肺吸虫がヒトに感染した場合之同様, 虫体は十分に 成熟しないまま胸腔内を移行し, その結果, 自然気胸,
胸水貯留, 胸痛などが主な症状となる ${ }^{23)}$ 。また肺吸虫は, 肺以外の臓器・組織に迷入・異所寄生すること屯多く （脳・目・皮下など）, 虫体の侵入部位に応じた症状を認 めることがある。

肺吸虫の感染源となる淡水産力二の生食習慣がない我 が国で，かつて肺吸虫症が流行していた。 その理由は, カ二の処理に用いた包丁やまな板を介して, メタセルカ リアが次に調理される野菜などを污染し，その野菜を非 加熱で摂食して感染するからだと説明されてきた ${ }^{15)}$. こ のようないわば古典的な肺吸虫症の流行は, 現在では, ほぼ終息したと考えられている.

一方で，イノシシが淡水産のカ二（特にモクズガニ） を捕食して, 肺吸虫の幼虫（主に 3 倍体型のウェステル マン肺吸虫）を筋肉内に蓄積し，患者発生に重要な役割 を果たすことが，1970 年代に九州南部で証明された ${ }^{24)}$. イノシシのような動物を「中間宿主」と区別して，「待機 宿主」と呼ぶ。現在でも，イノシシ肉の生食（非加熱摂 食）の機会が多いハンターやその家族・関係者を中心 に, 肺吸虫の感染が集団事例を含め, 西日本を中心に続 いている.

この十数年来の話題として，アジア系外国人における 肺吸虫症例の発生を挙げることができる ${ }^{13)}$. モクズガニ やサワガニを食材とした出身地固有の料理を加熱なしで 賞味し，肺吸虫に感染する事例である。このような料理 の一例がモクズガ二の老酒漬 (酔蟹) である. 本稿では これに関連する話題として，2004年の秋に佐賀県にお いて発生した集団感染事例（4名が感染）に関し，届出 の経緯と原因調査の結果を中心にして述べてみたい。併 せて，アジア系外国人における肺吸虫症の発生と，その 原因食材となる市販サワガニの肺吸虫污染の実態につい て紹介したい.

\section{佐賀県で発生した肺吸虫症の集団感染事例}

表記の事例が届け出られた契機は, 神奈川県内の病院 に呼吸器症状で入院した患者（1名）を，担当医がウェ ステルマン肺吸虫感染と疑い, 佐賀県でのモクズガニの 食歴を確認し，血清学的に診断したことにある。さらに 担当医は，「ウェステルマン肺吸虫による食中毒疑いの 患者が入院」と神奈川県に連絡し，これを受けて神奈川 県が，佐賀県に事例発見を知らせた。直ちに佐賀県が調 査に取り組み，佐賀県の某料理店で老酒漬モクズガニを 114 名が摂食し, 上述の患者を含めて合計 4 名が感染し たことを明らかにした（2名は呼吸器症状を呈する有症 者, 2 名は血清反応のみ陽性の無症者)。そして, 地元保 健所長加ら県知事に, さらに厚生労働省に, ウェステル マン肺吸虫による食中毒事件発生の届出がなされ た7,26).このように自治体は, 医師からの届出があれば, 連携して食中毒に対応する行政上の機関であることを， ここに紹介しておきたい.

当該事例の原因食品となったモクズガニは，県北西部 
を流れる玉島川で捕獲されていた。事例発生後に改めて モクズガニを採集し, 69 匹について肺吸虫メタセルカ リアの寄生状況を検査した. その結果, 肺吸虫陽性の個 体は 13 匹で, 寄生率は $19 \%$ と高くはなかった。しかし 陽性のモクズガニの中には, 167 個あのメタセルカリア が検出された個体も含まれていた ${ }^{25)}$. このように寄生数 の極めて多いモクズガニが混在していたことを原因とし て, 一部の感染者, 例えば当該事例発見の契機となった 神奈川県の症例で, モクズガ二摂食後 8 日という早期か ら, 症状が観察されたと考えられた.

原因河川であった玉島川の漁業協同組合関係者に対し て，地元住民の肺吸虫に関する知識の有無を尋ねた。地 元では「モクズガニには肺吸虫がいる」と認識する者屯 多く, したがって「モクズガニは必ず加熱調理する」と いう回答を得た。しかしながら，当該事例の原因施設で ある料理店の調理担当者はこれを知らず, 地元産モクズ ガニは安全であると䛊認して, 今回の事故を発生させ た.このような形での肺吸虫症の発生を予防するには, 料飲店関係者に対して, 肺吸虫症の原因となる淡水産の カニ（モクズガニ, サワガニ) を提供するなら十分に加 熱するように徹底した啓発を行い，これを継続する必要 がある。このような啓発活動は, 感染症・公衆衛生関係 の専門家及び地方自治体の医療保健行政担当者の責務と なる。

\section{食用に販売されていたサワガニにおける肺吸虫污染}

アジア系の外国人（中国人・韓国人・タイ人等）は, 淡水産の力二を食材として積極的に利用し，これを加熱 なしで摂食する固有の食文化を持つ. 我が国に在住する 間む, 彼らはこの食習慣を維持し, 時に日本産の肺吸虫 に感染する. 飲食を共にすることで日本人屯感染してお り, 輸入食習慣に起因する新たな肺吸虫症の流行とし て，注意の必要がある ${ }^{13)}$.

これら外国人の肺吸虫症事例では, 市販のサワガニが 原因食材となった場合も多い。そこで我々は, 市販の食 用サワガニに注目して調査を行い, 肺吸虫メタセルカリ アがサワガニを高率に污染し, 非常に危険である事実を 警告してきた ${ }^{29)}$. 以下にその知見を整理し，サワガニを 感染源とする肺吸虫症で起こりうる問題点を指摘した w.

生鮮魚介類を取扱う東京都内の小売店で, 2004 年 4 月から 2008 年 2 月に, 合計 266 匹の食用サワガニを購 入し, 肺吸虫メタセルカリアの寄生状況を調べた. その 結果, 44 匹 $(17 \%)$ からメ夕セルカリアが検出された. これらは, 形態及び塩基配列から肺吸虫の種類に関する 同定を試みたところ, 多くが宮崎肺吸虫であり, さらに ウェステルマン肺吸虫（2 倍体型・3 倍体型）屯認める ことを明らかにした。 また福岡市で市販されていた食用 サワガニからも, 宮崎肺吸虫のメタセルカリアが検出さ れた ${ }^{28,30)}$. 我が国で食用として流通するサワガニは, 肺
吸虫症の原因食品として危険であり，摂食するのであれ ば十分な加熱が必要である。関係者には, この事実の発 信・啓発をお願いしたい.

食用として市販されていたサワガニからは, 我が国で の人体寄生種である肺吸虫のメ夕セルカリアがすべて検 出された。 すなわち, サワガニを原因として肺吸虫に感 染した場合, ウェステルマン肺吸虫（3 倍体型）による 咳漱・血痰を主徵とする事例と, ウェステルマン肺吸虫 （2 倍体型）あるいは宮崎肺吸虫による気胸・胸水を主 徵とする事例が, 共に起こりうる可能性が示唆された。 さらに，複数種（複数型）の肺吸虫に同時感染する事例 の発生む危惧していたところ, 実際に, ウェステルマン 肺吸虫（3 倍体型）と宮崎肺吸虫の虫卵を喀痰中に認め る 1 症例を経験した (高坂ら, 投稿準備中). サワガニを 原因食品とする肺吸虫症では病態が複雑となり, さらに 血清学的な手法による原因虫種の特定が困難となる場合 も懸念される。注意が必要である。

\section{肺吸虫症例の発生実態と届出}

肺吸虫症の発生状況を, 食中毒統計に見てみたい（表 2). その数は残念ながら著しく少なく, 上述の 2004 年 に佐賀県で感染した患者 4 名の事例のほかには, 2007 年に福岡市で発生した患者 2 名の 1 件しか届出がない. 寄生虫症の血清診断に積極的に取り組む宮崎大医学部寄 生虫学教室では, 年間に 30〜 40 例の肺吸虫症例を経験 されるとのことから ${ }^{21)}$ ，我が国では年間に 50 例を超え る肺吸虫症例が発生しているのは疑いないが，実際の届 出数はこれに遠く及ばないのが現状である.

\section{ホタルイカの生食による旋尾線虫症}

話題を旋尾線虫に変えたい，旋尾線虫（X 型幼虫，「X 型」は「じゅうがた」と読む) による幼虫移行症は, 1980 年代半ばから知られるようになってきた新顔の寄生蝡虫 症である。ヒト以外の動物を固有宿主とする寄生蠕虫の 幼虫が，ヒトに感染しても成虫に発育することなく，幼 虫のままで人体内を移行し, さまざまな症状（症候群） を引き起こすことがある，これを幼虫移行症と呼んでい る.

旋尾線虫による幼虫移行症は, ホタルイカの生食後 に，主として腸閉塞あるいは皮膚爬行症の形で発症す る。 ホタルイカは従来, 限られた産地でのみ非加熱で賞 味されてきた。しかし漁獲から運搬に至る技術の進歩 （コールドチェーンの普及）により, 生鮮状態での遠隔地 輸送が可能となった。この結果, 本症が日本の各地で発 生するようになった。

本虫の幼虫は, 感染源となるホ夕ルイカのほかに, ス ケトウダラ, 八夕ハ夕，スルメイカ，アンコウからも検 出されていた。 しかしながら, 成虫及び終宿主が長く不 明であったために, 分類学的な位置 (種名) が確定して いなかった，最近の研究により，本虫は旋尾線虫亜目の 
Crassicauda giliakiana であり, 終宿主はツチクジラで, その腎臓に成虫が寄生することが明らかにされた ${ }^{27)}$.

\section{旋尾線虫症の予防対策}

旋尾線虫の感染を予防して，ホタルイカを安全に摂食 するという観点から，ホタルイカの処理方法について検 討が行われた。その結果,

1. $-30^{\circ} \mathrm{C}$ で 4 日間以上などの冷凍

2. 沸騰水で 30 秒，むしくは中心温度で $60^{\circ} \mathrm{C}$ 以上の 加熱

という条件が，本虫の感染予防に有効なことが明らかに された.この検討結果を踏まえて, 生食用のホタルイカ を販売するに際しては，上述の条件で冷凍する，内臓 (虫体の主要寄生部位) を除去する，あるいは内蔵を除去 してから生食する旨を表示する，のいずれかの方法を採 用するように，当時の厚生省から各都道府県知事等に通 知が発出された ${ }^{18)}$. このような取り組みが, 以後の症例 数の減少にも貢献していると考えられる.しかしなが ら, 旋尾線虫による症例の報告は継続しており, 食中毒 としての届出屯認める (表 2). 発生予防に関する啓発活 動を継続することが重要となる.

\section{おわりに}

本稿では, 食品衛生法における寄生虫症の取扱いにつ いての説明から始め，法に則した届出が実際に認められ るアニサキス, 肺吸虫及び旋尾線虫について, 最近の話 題を交えて概説した。

飲食に起因する衛生上の危害は，原虫・蠕虫のいずれ が原因物質である事案であっても, 食品衛生法に則した 食中毒としての届出が必要となる。これが徹底されれ ば，食品における寄生虫污染の実態及び当該疾患の発生 状況が正確に把握されるようになり, 病気の発生予防に も役立つことが期待される。

届出に際しては，食中毒部会で検討・指定された 14 種類の寄生虫, また「食中毒病因物質の分類」に例示さ れた 3 種類の寄生虫が一つの目安となる。しかしなが ら，飲食に起因する健康被害があれば，原因の寄生虫の 種類が何であれ，食中毒として届け出るというのが，厚 生労働省の見解である. 何より屯, 医師からの届出, さ らに医師以外の者からの報告等が重要である。この点を 最後に改めて指摘しておきたい.

\section{謝 辞}

本稿に関連する情報を提供していただき，また本稿に 対して貴重な意見をいただいた共同研究者・関係者の各 位に感謝いたします。

\section{文献}

1）安藤由紀男, 林 幸夫, 畑 英一, 新村宗敏, 小島莊明: 千葉県鴨川市及び周辺地域において発生したアニサキス
症，即時型アレルギー様症状を伴った集団発生例。寄生 虫誌，41(1・補)， 81 (1992).

2) Asami, A., Watanuki, T., Sakai, H., Imago, H. and Okamoto, R.: Two cases of stomach granuloma caused by Anisakis-like larval nematodes in Japan. Am. J. Trop. Med. Hyg., 14, 119-123 (1965).

3) Audicana, M. T., Ansotegui, I. J., Corres, L. F. and Kennedy, M. W.: Anisakis simplex: Dangerous-dead and alive? Trends Parasitol., 18, 20-25 (2002).

4) Audicana, L., Audicana, M. T., Corres, L. F. and Kennedy, M. W.: Cooking and freezing may not protect against allergenic reactions to ingested Anisakis simplex antigens in humans. Vet. Rec., 140, 235 (1997).

5) Audicana, M. T. and Kennedy, M. W.: Anisakis simplex: From obscure infectious worm to inducer of immune hypersensitivity. Clin. Microbiol. Rev., 21, 360-379 (2008).

6) Dawson, D.: Foodborne protozoan parasites. Int. J. Food Microbiol., 103, 207-227 (2005).

7）平野敬之, 増本久人, 船津丸貞幸, 藤原義行, 池添博士, 杉元昌志, 松㠃祐己, 森田満雄, 杉山 広, 森嶋康之, 荒 川京子，川中正憲：平成 16 年秋に集団発生した肺吸虫 による食中毒事例について. Clin. Parasitol., 17, 60-62 (2006).

8）飯野治彦, 内田 哲, 今村和之, 古沢 毅, 柴田興彦, 松 本興三, 須古博信, 福田 実, 山下行博, 長谷川英男, 安 里龍二：九州のアニサキス症一 $1 \sim 8$ 次アンケート調 査・総まとめ（1962 年 3 月～1990 年 6 月）。臨床と研 究, 70, 3563-3576 (1993).

9）唐澤洋一，平福一郎，星 和夫：最近の消化管アニサキ 又症一第 2 回全国集計調査一. 日医事新報, (4386), 6874 (2008).

10) Kasuya, S., Hamano, H. and Izumi, S.: Mackerelinduced urticaria and Anisakis. Lancet, 335, 665 (1990).

11）粕谷志郎：アニサキスとじんま疹. 病原微生物検出情報, 25, 119-120 (2004).

12) 粕谷志郎, 古賀香理：Anisakis 関連疾患における特異 IgE 測定の意義. アレルギー，41，106-110 (1992).

13）川中正憲, 荒川京子, 森嶋康之, 杉山 広: 在日外国人固 有の食習慣に起因する肺吸虫症. 病原微生物検出情報, 25, 121-122 (2004).

14）川中正憲，荒木 潤：アニサキス症一発生状況とその予 防一. 食品衛生研究， 56, 17-22 (2006).

15) Komiya, Y., Yokogawa, M., Shichijo, K., Nishimiya, H., Suguro, T. and Yamaoka, K.: Studies on paragonimiasis in Shizuoka Prefecture. I. An epidemiological survey of Paragonimus westermani along the banks of the Kano River. Jpn. J. Med. Sci. Biol., 5, 341-350 (1952).

16）厚生省生活衛生局長：食品衛生法施行規則の一部を改正 する省令の施行等について。食品衛生研究，50(2), 114116 (2000).

17）厚生省生活衛生局食品保健課長・乳肉衛生課長：食品媒 介の寄生虫疾患対策等について。食品衛生研究，47(11), 86-95 (1997).

18）厚生省生活衛生局食品保健課長・乳肉衛生課長：生食用 ホタルイカの取扱いについて. 病原微生物検出情報, 25 , 
115 (2004).

19）厚生省生活衛生局食品保健課長・乳肉衛生課長・食品化 学課長：食中毒統計作成要領の一部改正について. 食品 衛生研究, 50(2), 117-120 (2000).

20）熊谷優子：我が国における食中毒対策の取り組み〜食中 毒被害情報管理室の行政上の役割〜。獣会誌, 62 , 902-907 (2009).

21) 丸山治彦，名和行文: 肺吸虫. 日胸, 66, 269-275 (2007).

22) Mattiucci, S. and Nascetti, G.: Molecular systematics, phylogeny and ecology of anisakid nematodes of the genus Anisakis Dujardin, 1845: An update. Parasite, 13, 99-113 (2006).

23）宮崎一郎：医学上重要なベルッ肺吸虫. 福大医紀，9, 221-232 (1982).

24）宮崎一郎, 木船悌嗣, 寺崎邦生, 岩田久寿郎, 広瀬浩士： 若いウェステルマン肺吸虫一イノシシの筋肉に自然感 染一。 日医事新報, (2748), 23-25 (1976).

25) 杉山 広, 森嶋康之, 荒川京子, 川中正憲, 平野敬之, 増 本久人, 池添博士：平成 16 年秋に集団発生した肺吸虫 による食中毒事例一原因の寄生虫学的精査一. Clin. Parasitol., 19, 63-66 (2006).

26) 杉山 広, 森嶋康之, 荒川京子, 川中正憲, 平野敬之, 増 本久人, 舩津丸貞幸, 藤原義行, 池添博士, 杉元昌志, 松 㠃祐己, 森田満雄：2004 年秋に集団発生した肺吸虫によ る食中毒事例について。病原微生物検出情報, 27, 277278 (2006).

27）杉山 広, 森嶋康之, 荒川京子, 木白俊哉, 川中正憲：旋 尾線虫をめぐる新しい展開. 寄生虫分類形態談話会報, 25, 4-7 (2007).

28) 杉山 広, 梅原梓里, 森嶋康之, 川中正憲, 山﨑 浩: 市 販サワガニを対象とした肺吸虫メタセルカリアの寄生状 況調查. Clin. Parasitol., 19, 89-91 (2008).

29）杉山 広, 梅原梓里, 森嶋康之, 川中正憲, 山嵪 浩: 食
用として販売されていたサワガニからの肺吸虫メタセル カリアの検出. 病原微生物検出情報, $29,284-285$ (2008).

30) Sugiyama, H., Umehara, A., Morishima, Y., Yamasaki, H. and Kawanaka, M.: Detection of Paragonimus metacercariae in Japanese freshwater crab, Geothelphusa dehaani, bought at retail fish markets in Japan. Jpn. J. Inf. Dis., 18, 252-253 (2009).

31) Suzuki, J., Murata, R., Hosaka, M. and Araki, J.: Risk factors of human Anisakis simplex infection and association between the geographical origins of Scomber japonicus and anisakid nematodes. Int. J. Food Microbiol., 137, 88-93 (2010).

32) Umehara, A., Kawakami, Y., Araki, J., Matsui, T. and Uchida, A.: Molecular identification of Anisakis simplex sensu stricto and Anisakis pegreffii (Nematoda: Anisakidae) from fish and cetacean in Japanese waters. Parasitol. Int., 55, 267-271 (2006).

33) Umehara, A., Kawakami, Y., Araki, J. and Uchida, A.: Molecular identification of the etiological agent of the human anisakiasis in Japan. Parasitol. Int., 56, 211-215 (2007).

34) Umehara, A., Kawakami, Y., Araki, J., Uchida, A. and Sugiyama, H.: Molecular analysis of Japanese Anisakis simplex worms. Southeast Asian J. Trop. Med. Public Health, 39(Suppl. 1), 26-31 (2008).

35）梅原梓里, 杉山 広, 川上 泰, 内田明彦, 荒木 潤: 同 胞種レベルでみた日本産 Anisakis simplex：感染源の特 定に向けた検討. Clin. Parasitol., 19, 114-117 (2008).

36) van Thiel, P. H., Kuipers, F. C. and Roskam, R. T.: A nematode parasitic to herring, causing acute abdominal sydromes in man. Trop. Geographic. Med., 2, 97113 (1960). 